\title{
How the refugee crisis and radical right parties shape party competition on immigration
}

\author{
Theresa Gessler ${ }^{1}$ (D) and Sophia Hunger ${ }^{2 *}$ (1) \\ ${ }^{1}$ Department of Political Science, University of Zurich, Zurich, Switzerland and ${ }^{2}$ Center for Civil Society Research, WZB \\ Berlin Social Science Center, Berlin, Germany \\ *Corresponding author. Email: sophia.hunger@wzb.eu
}

(Received 23 July 2020; revised 15 June 2021; accepted 20 June 2021; first published online 15 November 2021)

\begin{abstract}
While the structure of party competition evolves slowly, crisis-like events can induce short-term change to the political agenda. This may be facilitated by challenger parties who might benefit from increased attention to issues they own. We study the dynamic of such shifts through mainstream parties' response to the 2015 refugee crisis, which strongly affected public debate and election outcomes across Europe. Specifically, we analyse how parties changed their issue emphasis and positions regarding immigration before, during, and after the refugee crisis. Our study is based on a corpus of 120,000 press releases between 2013 and 2017 from Austria, Germany, and Switzerland. We identify immigration-related press releases using a novel dictionary and estimate party positions. The resulting monthly salience and positions measures allow for studying changes in close time-intervals, providing crucial detail for disentangling the impact of the crisis itself and the contribution of right-wing parties. While we provide evidence that attention to immigration increased drastically for all parties during the crisis, radical right parties drove the attention of mainstream parties. However, the attention of mainstream parties to immigration decreased toward the end of the refugee crisis and there is limited evidence of parties accommodating the positions of the radical right.
\end{abstract}

Keywords: Immigration; radical right; party competition; refugee crisis; text-as-data; mainstream parties

The literature on party competition has typically stressed long-term trends. However, change to the political agenda may also occur quickly, facilitated by extraordinary events: In 2013, immigration was a minor concern in the German elections with less than five percent of parties' media statements dedicated to the issue. At the next election in 2017, 19 percent of such statements concerned immigration (Hutter and Kriesi, 2018). This can be interpreted in different ways. Was it the long-term transformation of the German party system and the rise of the immigration-critical Alternative for Germany (AfD)? Or was it events external to the party system such as the humanitarian crisis of 2015 and Merkel's handling of it that played a pivotal role here? In short: What determines the changing politicization of immigration in Germany and elsewhere?

We argue that events like the 2015 crisis play a crucial role in the short-term politicization of issues. We build on two findings: Among long-term trends, scholarly literature has established the role of radical right parties in increasing the salience of immigration (Kriesi et al., 2008; Alonso and da Fonseca, 2012; Green-Pedersen and Otjes, 2017; Dancygier and Margalit, 2019). However, research has also established that attention to issues few citizens have personal experiences with-like immigration-crucially depends on information through media and public discourse (Green-Pedersen, 2019, p. 83). Building on this, we argue that both factors interact: 
events like the humanitarian crisis of 2015 move an issue into the spotlight. This provides radical right parties with an opportunity to further politicize immigration (e.g. Mader and Schoen, 2018). Moreover, they increase the pressure on mainstream parties to respond to their radical right challengers-a crucial factor that previous research has highlighted (Bale, 2003; Meguid, 2005, 2008; Bale et al., 2010; Van Spanje, 2010; Meyer and Rosenberger, 2015; Green-Pedersen and Otjes, 2017). So how does the pressure of rising public attention to immigration change mainstream parties' reactions to the radical right in terms of salience and positional change?

We test our argument with a dynamic analysis of party competition around immigration in the context of the 2015 refugee crisis in Austria, Germany, and Switzerland. For this, we compile a novel data set on parties' immigration emphases and positions at the monthly level based on press releases. This allows us to disentangle the different mechanisms in very short time intervals and to study the interaction between the external shock of the crisis and the continued pressure by radical right parties. Most scholarly work on the politicization of immigration and the role of radical right parties has built on temporally coarse "snapshot data" coming from electoral manifestos and election campaign coverage that lack a more-fine grained, dynamic account of changes. Hence, we advance research on immigration politicization by zooming in on the refugee crisis. This is important for two reasons. First, events like the humanitarian crisis of 2015 rarely coincide with elections so that classical campaign-centered approaches to party competition (e.g., Green-Pedersen, 2007; Hutter and Kriesi, 2019; Volkens et al., 2016) cannot gauge the impact of the crisis. Second, studying salience in very close, i.e. monthly, intervals enables us to uncover more immediate dynamics of how parties react to developments internal and external to the party system.

Our empirical approach incorporates three steps. First, out of 120,000 press releases from all major parties published between 2013 and 2018, we identify those concerned with immigration through a novel dictionary. The proportion of these immigration-related press releases provides us with a monthly measure of the each party's immigration salience. Second, we estimate parties' immigration positions using a Wordscores model. Finally, we use our measures for descriptive and time-series regression analyses.

We show that the crisis moved mainstream parties to address the immigration issue, regardless of its prior party-specific salience. Immigration salience increased for all parties with the beginning of the refugee crisis. In line with previous research, we show that radical right parties addressed immigration by far the most throughout the crisis period. However, increasing levels of salience by radical right parties are associated with an immediate rise in attention to immigration by mainstream parties. In contrast, we do not find the same for positions, where changes for mainstream parties are not clearly driven by radical right parties. We also qualify previous manifesto- and media-based studies' findings (Grande et al., 2019; Hutter and Kriesi, 2018) on the post-crisis period as we show that salience returns to the pre-crisis level for most parties toward the end of the crisis. Understanding the trend allows an interpretation of such snapshot data as part of a declining trend, rather than a sign of emerging politicization.

Overall, we contribute to the measurement of party positions on the immigration issue, as well as to the understanding of an important episode in European politics, the 2015 refugee crisis. We believe that studying parties' strategic responses to events in the field of immigration is crucialnot only for understanding the specific moment but also for the radical right's broader impact on the politicization of immigration as mediated through mainstream parties.

\section{Politics of immigration and the refugee crisis}

Our analysis builds on the premise that the refugee crisis had a direct effect and radically changed the importance of the immigration issue in the short run. ${ }^{1}$ We argue that highly salient public

\footnotetext{
${ }^{1}$ Note that our analysis focuses on the immediate consequences of the crisis and makes no assumptions on long-term consequences.
} 
events like crises have important indirect and immediate effects that change the "rules of engagement" on an issue. They put topics on the party-system agenda and hence force other parties to address an issue, whether it is beneficial to them or not. As changes in the salience of an issue may lead parties to adapt their positions (Abou-Chadi et al., 2020), crisis events have the power to reshape party strategies and may have long-lasting consequences.

We build our argument in several steps: First, we argue that the crisis increases the general salience of immigration due to parties' quest to appear responsive. Second, we posit that the crisis also changes the "rules of engagement" since it affects the reactions of mainstream parties to right-wing challengers whom the crisis presumably benefits. Third, we claim that the established incentives of party competition cause heterogeneity in this reaction that leads center-right parties to respond more strongly.

\subsection{The direct impact of the crisis}

Multiple factors determine parties' salience strategies (Green-Pedersen, 2019, pp. 24-40). While the literature has typically highlighted parties' ideological profile and the structure of party competition, we focus on more variable determinants. Specifically, we argue that events like the 2015 crisis have a powerful role in shaping salience strategies by increasing the so-called "problem pressure" (Green-Pedersen, 2019, p. 22). The enormous news coverage of the refugee crisis (Greussing and Boomgaarden, 2017; Harteveld et al., 2018) and the importance citizens attribute to the topic during this period (European Commission, 2018) force parties to address the issue.

Previous studies have shown that parties' salience and positional strategies often depend on the public salience of issues and issue priorities of voters (Sides, 2006; Klüver and Sagarzazu, 2016). Similarly, literature on election campaigns has argued that "riding the wave," i.e. campaigning on issues that dominate the news cycle, provides politicians with an immediate opportunity to appear concerned and responsive (Ansolabehere and Iyengar, 1994). Hence, we expect the salience of immigration in party competition to increase for all parties.

Hypothesis 1: Parties increase their attention to immigration with the start of the refugee crisis.

\subsection{Changing responsiveness to challengers}

However, our argument extends beyond a direct response to the crisis once we consider mainstream parties' responses to challenger parties, one of the main drivers of change in party competition (Hooghe and Marks, 2017; Hutter et al., 2018). We build our theoretical model on Meguid's seminal framework $(2005,2008)$ : She argues mainstream parties may respond to the electoral success of niche parties by (a) ignoring the issue, (b) actively mobilizing against the niche party's position with an adversial position, or (c) adopting the niche party's position to win back voters.

Applying this model to gauge mainstream parties' immediate reactions to challengers during a crisis, rather than long-term responses in the context of their electoral success, comes with important adaptations. Meguid's model assumes that reactions in terms of salience and positions are inherently tied. Extending her approach and applying it to shorter time intervals, we conceptualize mainstream parties' responses as a two-step decision: Parties first need to decide whether to address an issue more, i.e. increase its salience. In a second step, parties decide whether an increase in salience is accompanied by a change in their issue position. Namely, they may accommodate the challenger's positions, stick to their previous position, or articulate an explicit counter-position. This allows for courses of action which Meguid's framework does not foresee, e.g. parties may decide to engage with an issue without altering their position at all. While in some cases altering both salience and positions might seem beneficial, other situations may 
require strategic action only regarding salience. Separating these two dimensions of reactions is key when mainstream parties respond to external events that relate to the core issues of a challenger rather than the electoral success of that challenger. In such a situation, mainstream parties respond to updated evidence on the importance of a challenger's issue rather than on the popularity of its issue position. Hence, position change may seem less pressing.

Applying this framework to the refugee crisis, we note that despite their diverse ideological appeals, radical right parties are united in their anti-immigration mobilization (Betz, 2002; Fennema and Van Der Brug, 2003; Ivarsflaten, 2008). Given their strong emphasis on immigration, these parties have become associated with the issue in the minds of voters in Western Europe, i.e. they have developed a so-called "associative issue ownership" (Walgrave et al., 2012, p. 779; see also Mudde, 2010; Udris, 2012). ${ }^{2}$ We argue that the radical right's ownership of the immigration issue posits a dilemma to mainstream parties-particularly during times of heightened attention to the issue.

While we expect that all parties will pay increased attention to immigration in response to the crisis, we believe mainstream parties will additionally raise their responsiveness to radical right emphasis on immigration. As news coverage affects which issues voters base their choices on (Iyengar and Kinder, 1987), increased salience of an issue "owned" by a party may sway voters toward this party (Ansolabehere and Iyengar, 1994; Geers and Bos, 2017; Thesen et al., 2017). Thus, increasing attention toward immigration may benefit radical right parties and thereby put additional pressure on mainstream parties. To counter this, mainstream parties have to challenge the radical right's issue ownership: They can strive to re-gain issue ownership through showing engagement with the issue (Walgrave et al., 2012, 2015). This signals to voters that the party takes a policy problem seriously and does not leave it up to radical right competitors to search for solutions. We think this dynamic-which has mostly been investigated for longterm strategies-should also guide short-term responses as parties struggle to stay on top of the news cycle that may otherwise give a stage to challenger parties.

Thus, a crisis, which naturally attracts media coverage, changes the incentives of mainstream parties and makes them more likely to respond to challenger emphasis on an issue by also engaging with it. Hence, we expect that mainstream parties react to pressure from the radical right by addressing the immigration issue. This should go beyond the general increase in the salience of immigration we outlined in Hypothesis 1 and be driven by radical right parties' issue emphasis.

Hypothesis 2a: Mainstream parties' emphasis on immigration increases when radical right parties emphasize immigration.

While we argue that parties can hardly afford to ignore the immigration issue in reaction to the refugee crisis and radical right pressure, our two-step interpretation of Meguid's (2005) framework provides mainstream parties with more leeway regarding their positional reactions (see Figure 1). Hence, we inquire whether mainstream parties remain with their position, choose to actively mobilize against or adopt the radical right's position. While studies of party competition at large have emphasized the stability of party positions over time (Dalton and McAllister, 2015), much of the theoretical and case-study literature on immigration focuses on so-called (positional) contagion. These studies suggest that mainstream parties are prone to adjust their position to radical right parties (Bale, 2003; Bale et al., 2010; Van Spanje, 2010; Schumacher and van Kersbergen, 2016). However, results from quantitative, comparative research are inconclusive and show inconsistent effects (e.g., Meyer and Rosenberger, 2015; Green-Pedersen and Otjes, 2017).

\footnotetext{
${ }^{2}$ While radical right associative issue ownership of immigration is established in the literature, competence ownership is more volatile (Walgrave et al., 2009). However, even considering this second dimension, radical right parties are on average considered twice as competent as their competitors (Seeberg, 2017, own calculation).
} 
Given mainstream parties are unlikely to benefit from a long-term politicization of immigration and reactions in terms of position require more intra-party consultation, we expect them to avoid anything that would increase conflict on the issue. In a multi-party system where only the radical right clearly opposes immigration (as predominant in Western Europe), this means other parties should stick to their previous positions and maintain distance from the radical right. We expect parties to instead focus on the pragmatic politics of crisis management. While increasing the salience of immigration, this limits the politicization of immigration and is thus attractive to mainstream parties.

Hypothesis 2b: Mainstream parties do not adjust their position in response to the radical right.

\subsection{Partisan differences in responsiveness}

Despite our emphasis on the crisis, we do not presume that its effect occurs independent of other factors. Rather, external events interact with the existing context of party competition. Hence, we expect differences between party families' reactions which are grounded in their relation to the radical right and resulting different incentives to address immigration. Notably, an increasing strength of radical right-wing parties presents a more significant challenge for left-wing parties (Bale et al., 2010; Abou-Chadi, 2016) than for the right.

While increasing importance of immigration as vote-deciding issue may primarily favor the radical right, the tripolar structure of political competition (Kriesi et al., 2008, 2012) means immigration can help right-wing parties more broadly. With heightened attention to immigration, radical right challengers may succeed at mobilizing so-called left-authoritarian voters (Van Der Brug and van Spanje, 2009; Lefkofridi et al., 2014) that might otherwise vote for centerleft parties. Here, they do not work as competitors of mainstream right parties but help attract cross-pressured voters toward the right side of the party spectrum (Abou-Chadi, 2016). This means, even if center-right parties do not manage to gain voters, an increase in the strength of the parliamentary right may provide center-right parties with the opportunity to form a right-of-center coalition. These incentives for center-right parties should especially hold during crises when left-authoritarian voters may be more attentive to immigration. Hence, we expect the outlined salience-based contagion of the radical right to be stronger for center-right parties:

Hypothesis 3a: The radical right-driven increase in salience is stronger for center-right parties than for other mainstream parties.

We are more hesitant regarding positional contagion but suspect center-right parties may be tempted to adopt tougher stances on immigration. This may be driven by the risk of losing voters to intra-block competition: If voters choose depending on parties' immigration stances during the crisis (Mader and Schoen, 2018), fear may drive right voters toward the radical right. This makes it more attractive for center-right parties to accommodate immigration-critical stances to prevent a restructuration within the right camp. Another reason is that if the radical right indeed gains in strength following a more permanent politicization of immigration, radical right parties become potential coalition partners whom center-right parties may want to appease (Abou-Chadi, 2016, p. 423; also Bale, 2003). Thus, an increase in positional competition on immigration may broaden rather than limit coalition possibilities for the center-right. Hence, different from the stability we expected in Hypothesis 2b, we posit:

Hypothesis 3b: Center-right parties adjust their position in response to the radical right.

Figure 1 summarizes our expectations. In Hypothesis 1, we outline a "crisis-effect" which leads all parties to increase their immigration salience. Furthermore, we argue that the crisis forces 


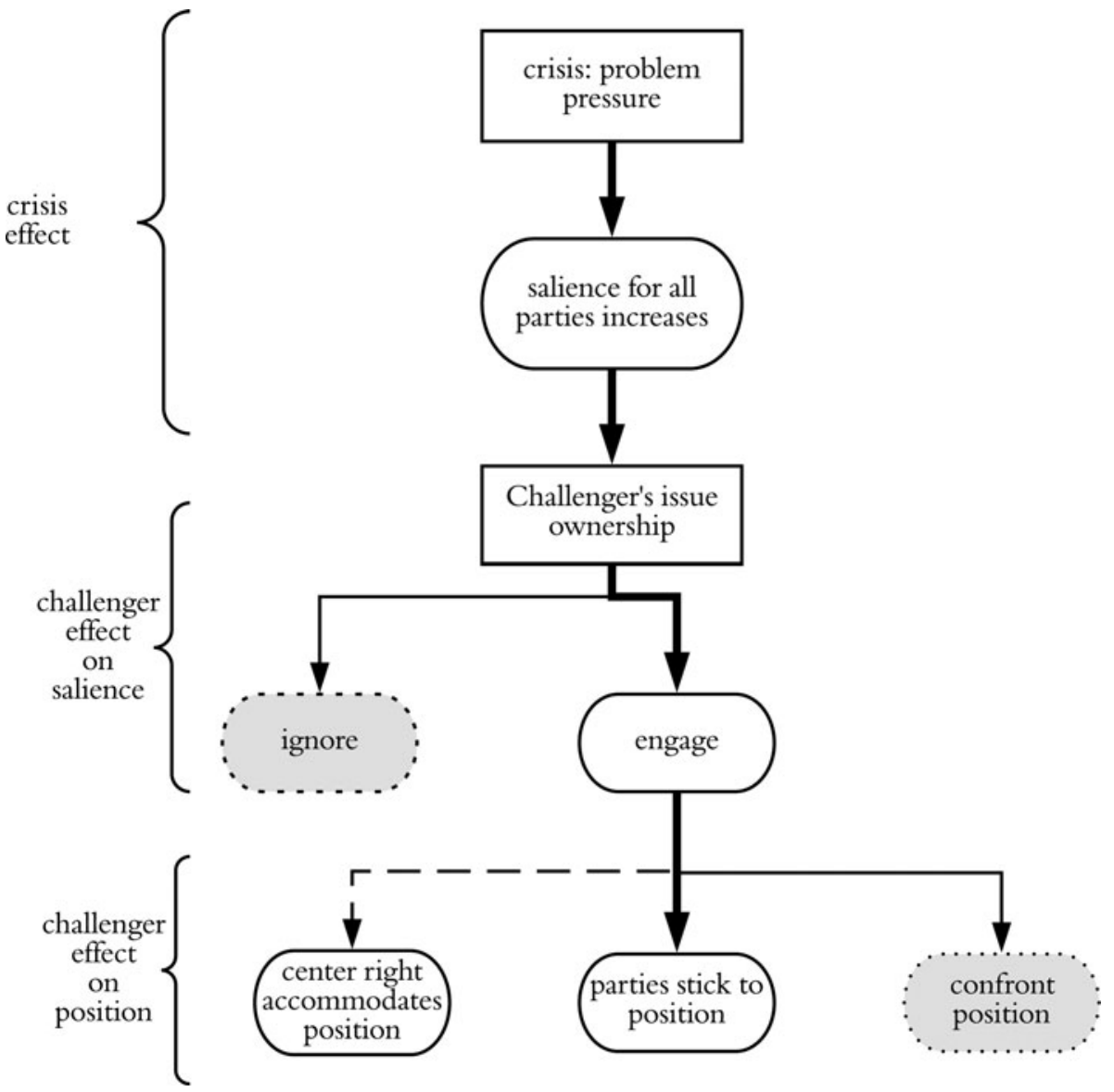

Figure 1. Full model of theoretical expectations.

mainstream parties to emphasize immigration in response to radical-right challengers to prevent the electoral success of these challengers (Hypothesis 2a). Despite this increased salience contagion, mainstream parties have little incentive to further politicize immigration by altering their issue positions (Hypothesis 2b). The crisis does, however, not overrule well-established incentives for particular party families. Hence, we expect stronger increases in salience for center-right parties (Hypothesis 3a). Additionally, center-right parties may accommodate their challengers' positions during the refugee crisis (Hypothesis $3 \mathrm{~b}$ ).

\section{Data and methods}

\subsection{Case selection}

As text-based measures of party strategies depend on language, we take a pragmatic decision to focus on Swiss, German, and Austrian parties that publish their press releases in German. While this selection is partially motivated by our methodological approach, we also think the three countries are representative of broader developments in Europe. In what follows, we situate our cases within patterns of party competition in Europe regarding immigration salience, the role of the radical right, and their exposure to the crisis.

Previous research has established a general trend of rising immigration salience across Europe, mirrored by our three countries under study. Figure 2 shows the salience of immigration 


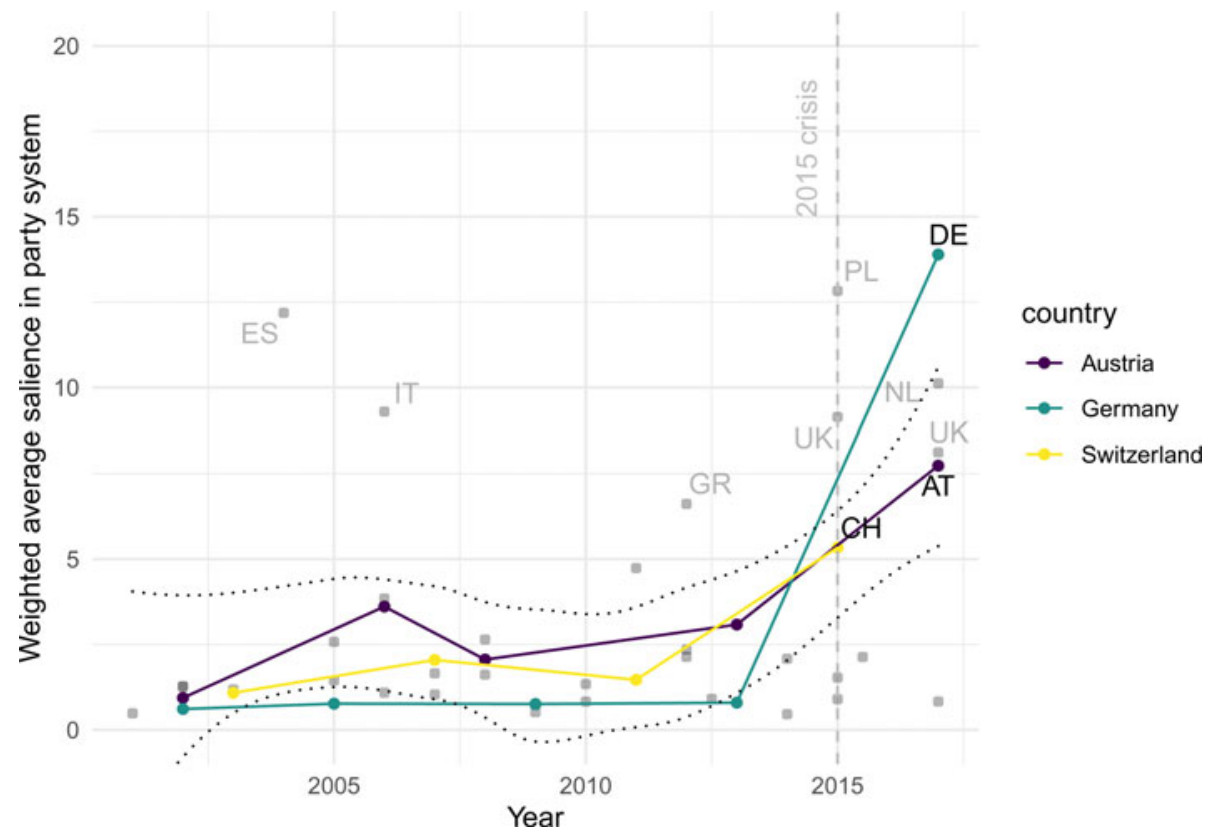

Figure 2. Salience of immigration in 14 European countries over time.

in election campaigns in 14 European countries (Kriesi et al., 2020). For Austria, Germany, and Switzerland we show patterned lines, while salience in the other countries is shown by grey dots with annotations for important outliers. The dotted area depicts the 95 percent confidence interval around the smoothed trend for all countries. Clearly, all three countries were typical rather than outlier cases compared to the European average, especially in the pre-crisis period.

While the 2015 crisis was clearly unique in each country, the countries under study experienced the 2015 crisis at least as much as other European countries. Figure 3 shows the yearly asylum applications in the 14 countries discussed above standardized per 100,000 inhabitants. While public debate and media reporting presented the German case as exceptional, Figure 3 shows that most European countries experienced a peak in refugee arrivals. ${ }^{3}$

Finally, since we argue that the crisis has generally empowered radical right parties to pressure their competitors, we shall emphasize the diverse histories of the radical right parties we treat as functional equivalents during the crisis: Both the Austrian Freedom Party (FPÖ) and the Swiss People's Party (SVP) were mainstream right parties that radicalized toward a nationalist, populist, and anti-immigration position during the 1990s (McGann and Kitschelt, 2005, p. 20; Kriesi et al., 2008 , p. 20). Hence, both parties have also been included in government coalitions. Given the Grand Coalition in the Swiss Federal Council, the SVP has been in government almost without interruption since its foundation. In contrast, the first FPÖ government participation after its ideological turn (in coalition with the center-right ÖVP in 2000) caused domestic and international protest. Nevertheless, the ÖVP both prolonged this coalition and entered another coalition with the FPÖ toward the end of our period of study in 2017. In contrast, the AfD emerged only after 2013. Initially a neoliberal anti-EU party (Bremer and Schulte-Cloos, 2019), the AfD established itself as an anti-immigration and anti-Islam party already before the crisis and entered

${ }^{3}$ We use a smaller smoothing parameter in this Figure given the coarse intervals. 


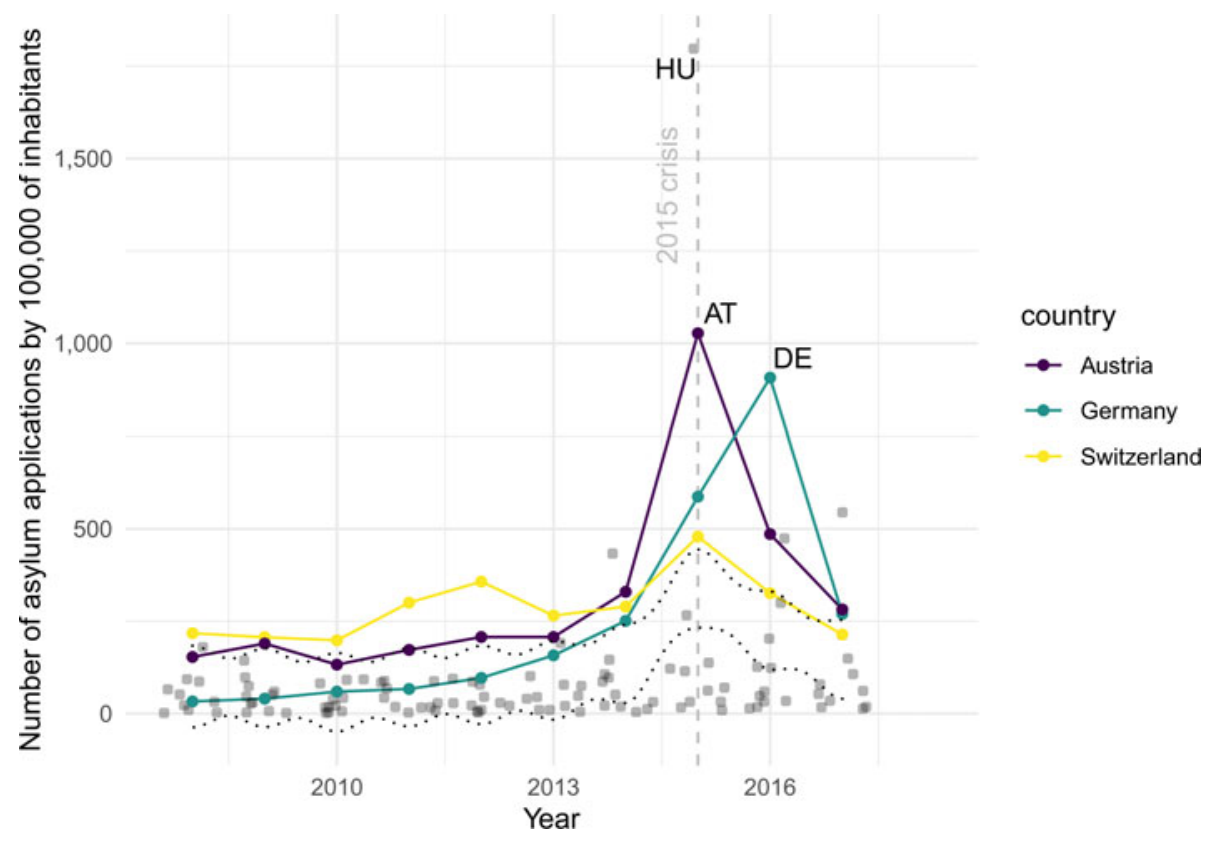

Figure 3. Annual Asylum applications in 14 European countries.

parliament in the 2017 election. However, none of its competitors considered the option of a coalition with the AfD, given its pariah status (Bräuninger et al., 2019).

\subsection{Research design}

Previous scholarship has often relied on party manifestos, which are written in a complex multistep process that involves diverse actors (Dolezal et al., 2012) and only published during election campaigns. We depart from this choice and introduce a novel data set of press releases from Swiss, German, and Austrian parties (see Table 1) which were published by party headquarters and parliamentary groups between January 2013 and March 2018. We collected releases from party web pages and national press release archives, resulting in up to 63 months per country and party. We include all parties that poll above the parliamentary threshold for most of our period of study. ${ }^{4}$

We argue that press releases are highly suitable for the assessment of parties' immediate and high-pace reactions to the crisis and radical right challengers, which might be missed by other more infrequent data sources. Press releases form a well-established and easily accessible routine tool for parties' day-to-day communications (Hopmann et al., 2012) that has little "institutional and resource constraints" (Meyer and Wagner, 2021). Thereby, they enable us to study immediate dynamics of agenda setting using empirical sources that are available continuously and mirror parties' changing strategies throughout the electoral cycle (Grimmer, 2013; Klüver and Sagarzazu, 2016).

The construction of our dependent variables (DVs) then follows a two-step logic drawing on quantitative text analysis (Benoit et al., 2018). First, we identify all immigration-related press

\footnotetext{
${ }^{4}$ This excludes Team Stronach which gained 5.7 percent in the 2013 elections but precipitously lost support afterwards and was dissolved in August 2017.
} 
Table 1. Number of press releases

\begin{tabular}{lrrrr}
\hline Party & $N$ (Total) & Monthly & $N$ (immigration) & Salience \\
\hline Austria & & & & 20.1 \\
FPÖ & 7981 & 126.7 & 1601 & 14.6 \\
Green Party & 5969 & 94.7 & 872 & 11.3 \\
NEOS & 2712 & 43.0 & 9963 & 13.7 \\
OVP & 7236 & 114.9 & 14 & 6.3 \\
Pilz & 221 & 27.6 & 1287 & 11.3 \\
SPÖ & 11,395 & 189.9 & 598 & 34.4 \\
Germany & & & 503 & 14.5 \\
AfD & 1736 & 28.9 & 294 & 20.1 \\
CDU & 3475 & 55.2 & 228 & 23.4 \\
CSU & 1463 & 21.5 & 556 & 16.3 \\
FDP & 973 & 27.8 & 917 & 17.8 \\
Green Party & 3403 & 55.8 & 416 & 10.7 \\
Left Party & 5165 & 82.0 & & \\
SPD & 3875 & 61.5 & 75 & 22.7 \\
Switzerland & & & 291 & 22.5 \\
BDP & 331 & 5.3 & 107 & 24.8 \\
CVP & 1294 & 19.3 & 46 & 17.8 \\
FDP & 432 & 8.6 & 140 & 14.6 \\
Green Liberal Party & 259 & 4.0 & 291 & 18.8 \\
Green Party & 962 & 14.4 & 11.8 & 53.5 \\
SPS & 803 & 8.1 & & \\
SVP & 544 & & & \\
\hline
\end{tabular}

releases using a dictionary. In a second step, we take these press releases and scale them from opposition to support immigration. The detailed approach is described below.

\subsubsection{A dictionary approach to immigration salience}

To measure attention to immigration, we develop a novel dictionary (see Appendix), based on a close reading of the press releases and drawing on previous approaches (Pauwels, 2011; Ruedin and Morales, 2017). In line with recommendations (Muddiman et al., 2018), we restrict our dictionary to words that refer to immigration and integration, avoiding overly specific terms as well as frequently used concepts that might lead to a conflation with diversity or religious rights, e.g. "minaret" and "christian."

We evaluated different approaches to identify immigration-related press releases based on more than 750 randomly-selected press releases which were hand-annotated by the authors. This procedure is considered to be the gold standard for our evaluation. The goal was identifying as many relevant press releases as possible without falsely including press releases on other topics. Our dictionary outperforms those used in previous research (Rooduijn and Pauwels, 2011; Ruedin and Morales, 2017) and performs on par with a support vector machine classifier (see Tables A1-A3, online Appendix). Given the computational efficiency and clearer decision-rules of the dictionary solution, we opt for our small dictionary rather than the SVM classifier. Overall, this offers the best compromise in terms of accuracy, interpretability, and computational efficiency. Table 1 presents the results of this classification.

\subsubsection{Measuring party positions with wordscores}

In a second step, we use these immigration-related press releases to scale parties' positions with Wordscores (Laver et al., 2003), a scaling technique that estimates political positions based on the similarity of word usage between a set of texts with known and unknown policy positions. Our pre-processing strategy follows standard recommendations (Lowe, 2008; Ruedin, 2013): we remove frequently used words that lack substantive meaning, stem the words, and remove words occurring less than four times. We have tested several pre-processing steps, such as 
removing names or relying exclusively on nouns, based on a parts-of-speech tagging pipeline. As results were not substantively different, we used the full texts.

Slightly deviating from previous applications, we calculated wordscores only based on substantively meaningful words. For this, we compare immigration-related and other texts to calculate keyness-statistics for each word. For estimating the wordscores model, we only keep words with a $\chi^{2}$ higher than zero. While this does not lead to systematically different results, it allows us to calculate party positions based on words that are substantively meaningful regarding immigration making human validation of our measures more credible.

As input for our Wordscore model, we use data on party positions in national election campaigns (Hutter and Gessler, 2019; Kriesi et al., 2020). These data are particularly suitable since it covers party positions at a specific moment in time, rather than expert surveys where scores may be influenced by past positions of a party. We only include parties with more than 100 immigration-related press releases (see Table 1). As Wordscores are systematically biased if the word distribution across the different reference texts is insufficient, we assign our reference scores to the press releases of the entire election month, which is roughly the same period for which the reference scores are valid.

\subsubsection{Modeling strategy}

We use our measures (namely, monthly party-specific salience measures as the share of immigration-related press and estimates of positions based on wordscores) for descriptive and regression analyses. This section discusses our modeling strategy as well as control variables.

We employ Arellano-Bond models (Arellano and Bond, 1991), a dynamic panel model estimator which allows for including lagged DVs and thus accounts for autoregression. Arellano-Bond models use a Generalized Method of Moments which includes deeper lags of the DV as instruments for endogenous lags of the DV. The model assumes a serial correlation structure: while the first-order lag of the DV is serially correlated to the DV, there must not be second-order serial correlation, i.e. the second lag may not be correlated with the DV. We test the model assumptions for our measures of salience and position, i.e. the two DVs in our models, using the Arellano-Bond test for serial autocorrelation (see Table A4, online Appendix).

Since our regression models aim at assessing the impact of the refugee crisis and radical right parties on other parties' salience and positions, we exclude radical right parties. In total, our sample consists of 209 party-months for Austria, 299 party-months for Germany, and 138 partymonths for Switzerland. For both DVs, we could not reject H0 of no correlation for the first-order lags, while we could reject it for the second-order correlations. Hence, the model assumptions are satisfied.

We use our concurrent measures of radical right parties' immigration salience and positions as main in DVs but also include the first lag of each of these measures in order to assess whether parties' response occurs with a delay. We control for radical right parties' electoral pressure and a country's exposure to the refugee crisis. As discussed, previous literature has often assumed the radical right's strength affects mainstream parties' motivation to address immigration. Thus, we include radical right parties' strength by using monthly polls of the FPÖ, AfD, and SVP. ${ }^{5}$

We include several measures to capture the crisis: For severity, we use the monthly number of asylum applications as research assumes that refugee arrival and the state's capacity to react determines the problematization of immigration in public discourse. Alternatively, we also consider that what mattered could be the perception of a crisis rather than the extent of refugee arrivals. Given the scarcity of opinion data over time, we rely on Google Search Trends to measure public attention to immigration. Specifically, we use the Google Knowledge Graph technology to track the frequency of a search query topic rather than individual search strings (Siliverstovs and

\footnotetext{
${ }^{5}$ We obtained polls from different agencies collected by poll of polls, neuwal.com, and the research projects VoxIt (Kriesi et al., 2016) and Voto (FORS, 2018).
} 
Wochner, 2018). In line with advice from previous applications (Granka, 2013; Mellon, 2013; Chykina and Crabtree, 2018), we compare different search trends with Eurobarometer results for immigration salience as the most important problem in a country and select the Google trend for "refugee" as closest correlate to the Eurobarometer in Germany and Austria. To delimit the crisis period, we additionally calculate a binary measure based on this series. We determine as refugee crisis the period in which the searches for the refugee topic are above the country average. Thereby, we place the start of the crisis in July 2015 in Austria, and in August 2015 in Germany and Switzerland. This period of heightened attention ends in July 2016 in Austria, in November 2016 in Germany, and in February 2017 in Switzerland, the first month in which attention to the topic falls below the mean. ${ }^{6}$

\section{Results}

\subsection{The rising salience of immigration}

We first address how much the salience of immigration has in fact risen during our period of observation. We start by presenting our measures of salience for each party in the three countries. Figure 4 visualizes our results in two ways: The points represent monthly averages of salience while the curves represent the trend using locally smoothed daily estimates. The gray lines in the background show the smoothed lines for the other national parties and the dashed vertical line the start of the refugee crisis.

The first set of plots in Figure 4 shows the salience in Austria. Clearly, all parties react to the crisis with increasing attention to immigration. This increase is most pronounced for the right-wing FPÖ, which already addressed the issue most before the crisis. In line with our expectations, ÖVP becomes the party with the second highest salience of immigration during the crisis, while previously the Greens primarily competed with the FPÖ on the issue. Nevertheless, the increase is relatively similar for all Austrian parties, except for a short period of divergence at the start of the crisis visible only in the point estimates.

In Germany, depicted in the second set of plots in Figure 4, the initial increase is steeper for several parties compared to Austria. Notably, differences between the parties are more pronounced: The right-wing AfD clearly stands out for its strong emphasis on immigration, especially compared to the Greens and Social Democrats that maintain a limited salience. We also find an interesting contrast between the strong increase of salience for the Bavarian CSU which differs from its federal-level sister party CDU. Generally, the sudden impact of the crisis in August is more apparent in Germany, as even AfD's emphasis on the issue was rather low in the months before the crisis. This is primarily visible in the distribution of monthly averages.

The third set of plots in Figure 4 shows the estimated salience in Switzerland. The baseline level of immigration salience is higher compared to most parties in the other countries. Overall, we only see a slight increase during the refugee crisis, and a slow decrease from mid-2016 onward. The SVP clearly stands out regarding its attention toward this issue. However, this is not a product of the crisis as the SVP emphasized immigration already beforehand, including a previous peak in early 2014 related to a popular initiative against so-called "mass immigration." A second period of increased emphasis for the SVP includes the period of the refugee crisis and continues throughout the 2015 Swiss elections, which gave the SVP an ideal opportunity to campaign on immigration.

Generalizing to the party system-level, the salience of immigration increased in all three countries. The difference between the radical right and its mainstream competitors is most notable in Switzerland where, comparing the general level of immigration salience, we also find a more steady attention to the issue. We suspect this difference is due to Switzerland's internal political

\footnotetext{
${ }^{6}$ Increases above the mean occur later on in Switzerland and Germany.
} 
A Salience of immigration in Austria

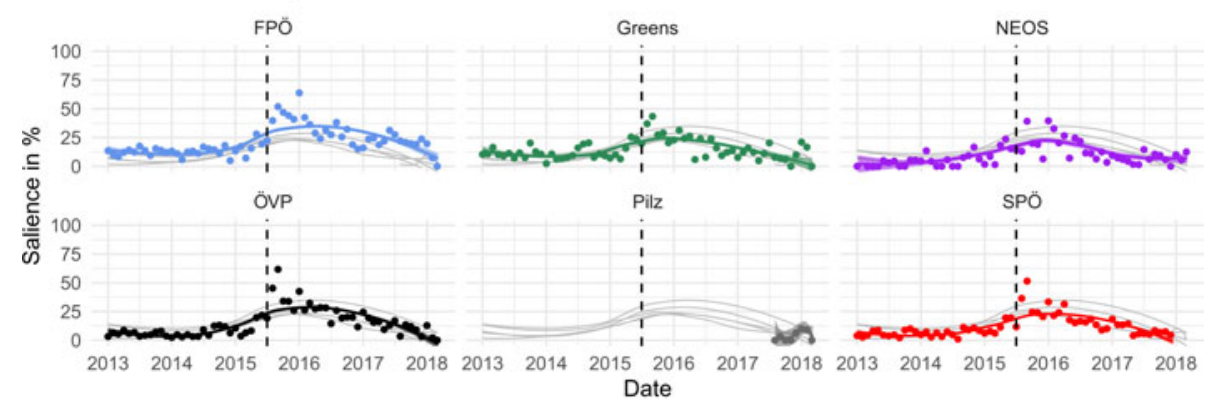

B Salience of immigration in Germany

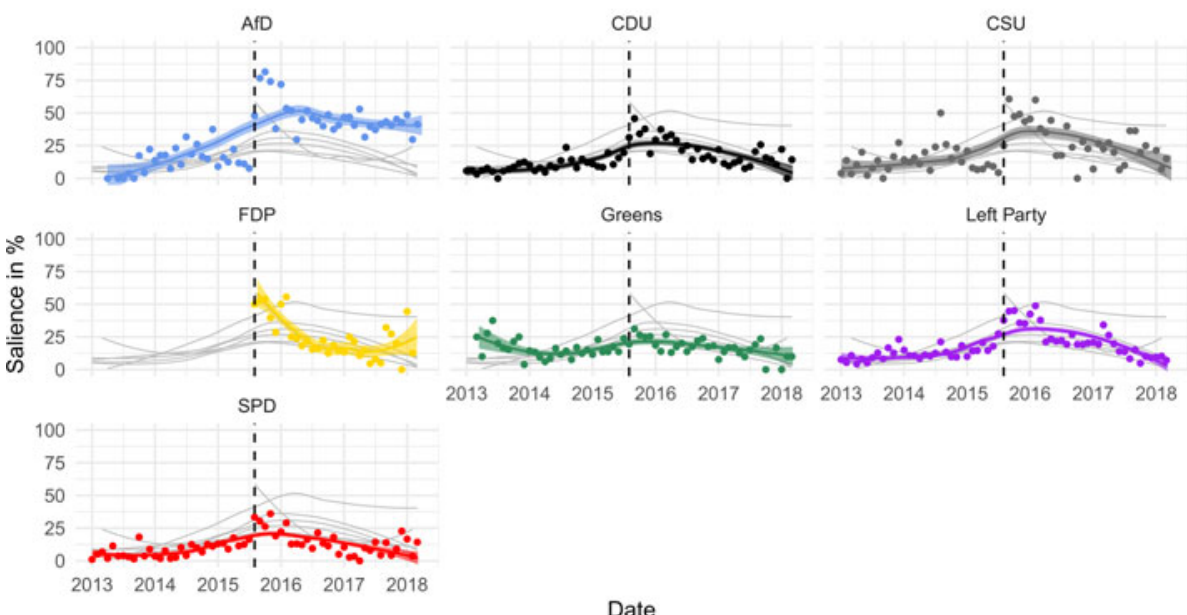

C Salience of immigration in Switzerland

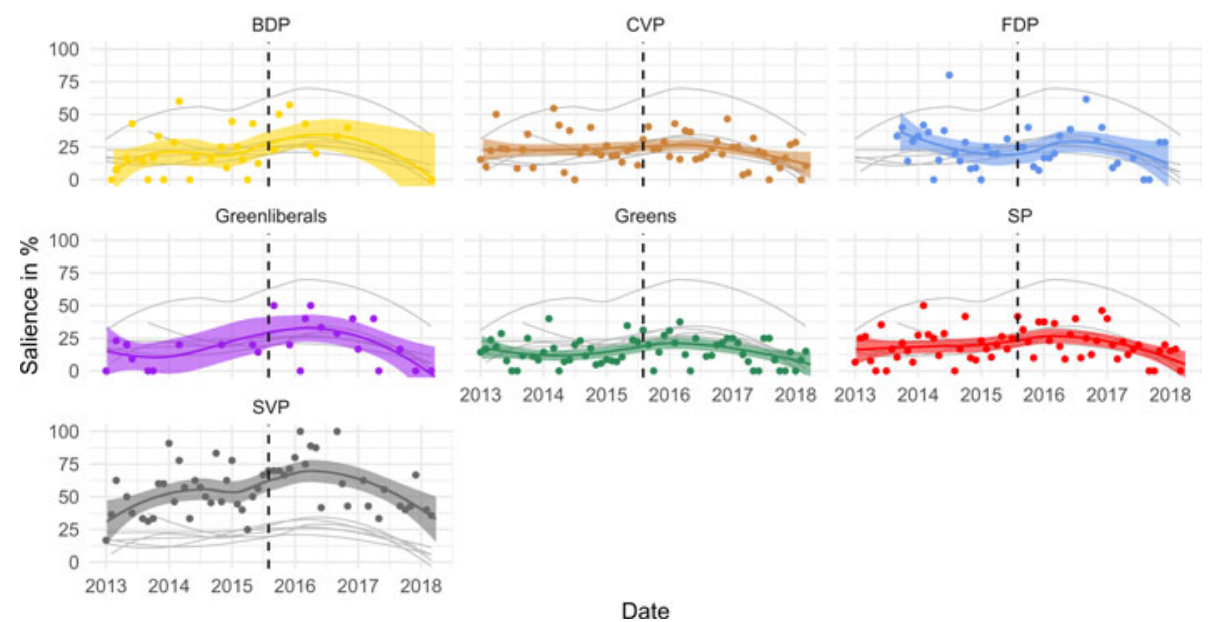

Figure 4. Estimated salience of immigration in three countries.

dynamic with the importance of popular votes as well as the relevance of immigration beyond forced migration, e.g. in the context of migration from the EU.

While the general increase in salience is certainly interesting, it is also important that the salience did not only increase drastically, but it also faded almost entirely after the crisis for most 
mainstream parties. This suggests that parties might have changed their strategy and tried to de-emphasize immigration once the immediate problem pressure decreased. Competing findings based on media reports, e.g. during election campaigns (Grande et al., 2019; Hutter and Gessler, 2019), suggest that the media might still have reported parties' immigration-related statements disproportionately, even though parties had started to avoid the issue.

\subsection{Dynamics of salience}

We now proceed to explicitly test our salience hypotheses in a regression framework. Table 2 presents eight models, first including all mainstream parties in our sample, then splitting the sample by country, time period, and finally including an interaction term for center-right parties. All models include the monthly number of asylum applications, public salience of immigration, and radical right parties' polls as control variables.

Our main independent variable of interest-radical right parties' concurrent immigration attention-is highly positively associated with increasing mainstream party attention toward the issue. This lends support to our hypothesis $2 \mathrm{a}$ as the direction of the effect is consistent across all models and, except for model 3 (Germany), statistically significant. Generally, radical right parties' salience contagion on mainstream parties remains positive and significant throughout the three time periods (models 5-7). The effect sizes vary across the models. In Austria, each 1 percent increase in radical right parties' salience accounts for an average increase of 0.32 percent for other parties, while the effect size is only 0.12 percent for all parties after the crisis. These findings indicate that radical right parties can pressure mainstream parties to increase their immigration salience. We note, however, that this effect is strongest in the period before the crisis: While the impact of contagion may be bigger during the crisis period, given the higher salience of the immigration issue, the radical right actually held most agenda setting power before the crisis. The first-order lag of RRPs' salience is only significant and positive in Switzerland, as well as for the combined model in the period before and after the crisis, which points toward a more immediate effect of RRPs' immigration politicization during the refugee crisis.

We test our expectation Hypothesis 3a that center-right parties react more strongly to radical right parties' increased issue emphasis by including an interaction term in model 8 . While the zero-finding of the center-right dummy shows that these parties do not generally dedicate more attention to immigration than other parties, the coefficient of the interaction term-positive and highly significant-suggests that center-right parties react more strongly to the behavior of radical right parties ${ }^{7}$ - both in terms of the concurrent and the first order lag of the radical right immigration salience. We find mixed results for our control variables, i.e. the monthly number of asylum applications, the public salience of immigration, and radical right parties' polls.

Overall, despite the stronger effect size before the crisis, we think the findings match our theoretical expectations and the descriptive results. The regression analyses show-even controlling an upward trend during the refugee crisis-that radical right parties' emphasis on immigration is positively related to mainstream parties' salience. In the next section, we move to parties' positions on immigration and assess their change during the refugee crisis.

\subsection{Party positions on immigration over time}

As parties have incentives to avoid increasing political conflict around immigration, we expect party positions to be more stable than the salience of the issue. We present the development of party positions in Figure 5 before we analyze their determinants with regression analyses. The first set of plots in Figure 5 shows the development of party positions in Austria. Most

\footnotetext{
${ }^{7}$ When running separate models for the three countries, see Table A5, online Appendix, the significance, however, only holds for Switzerland.
} 
Table 2. Regression results for mainstream parties' salience of immigration

\begin{tabular}{|c|c|c|c|c|c|c|c|c|}
\hline & $\begin{array}{l}\text { (1) } \\
\text { All }\end{array}$ & $\begin{array}{l}(2) \\
\text { AT }\end{array}$ & $\begin{array}{l}\text { (3) } \\
\mathrm{DE}\end{array}$ & $\begin{array}{l}\text { (4) } \\
\mathrm{CH}\end{array}$ & $\begin{array}{l}(5) \\
\text { Before }\end{array}$ & $\begin{array}{l}\text { (6) } \\
\text { During }\end{array}$ & $\begin{array}{l}\text { (7) } \\
\text { After }\end{array}$ & $\begin{array}{l}\text { (8) } \\
\text { Center-right }\end{array}$ \\
\hline RRP's salience of imm. & $\begin{array}{c}0.16^{* * *} \\
(0.04)\end{array}$ & $\begin{array}{c}0.32^{* * *} \\
(0.04)\end{array}$ & $\begin{array}{c}0.06 \\
(0.04)\end{array}$ & $\begin{array}{c}0.23^{* * *} \\
(0.05)\end{array}$ & $\begin{array}{c}0.22^{* *} \\
(0.09)\end{array}$ & $\begin{array}{c}0.15^{* * *} \\
(0.03)\end{array}$ & $\begin{array}{l}0.12^{*} \\
(0.07)\end{array}$ & $\begin{array}{l}0.10^{*} \\
(0.05)\end{array}$ \\
\hline RRP's salience of imm. (lag 1) & $\begin{array}{c}0.02 \\
(0.04)\end{array}$ & $\begin{array}{c}-0.10^{* *} \\
(0.04)\end{array}$ & $\begin{array}{l}-0.02 \\
(0.03)\end{array}$ & $\begin{array}{c}0.12^{* *} \\
(0.05)\end{array}$ & $\begin{array}{c}0.11^{* *} \\
(0.05)\end{array}$ & $\begin{array}{c}0.05 \\
(0.03)\end{array}$ & $\begin{array}{l}0.11^{* *} \\
(0.04)\end{array}$ & $\begin{array}{l}-0.02 \\
(0.03)\end{array}$ \\
\hline $\mathrm{CR}$ & & & & & & & & $\begin{array}{c}0.00 \\
(0.00)\end{array}$ \\
\hline Center-right * RRP's salience of imm. & & & & & & & & $\begin{array}{l}0.14^{* *} \\
(0.06)\end{array}$ \\
\hline Center-right * RRP's salience of imm. (lag1) & & & & & & & & $\begin{array}{l}0.10^{* *} \\
(0.05)\end{array}$ \\
\hline Asylum applications & $\begin{array}{c}1.03^{* * *} \\
(0.32)\end{array}$ & $\begin{array}{l}0.84^{*} \\
(0.45)\end{array}$ & $\begin{array}{c}1.30^{* * * *} \\
(0.41)\end{array}$ & $\begin{array}{c}1.06 \\
(0.90)\end{array}$ & $\begin{array}{l}2.89^{*} \\
(1.56)\end{array}$ & $\begin{array}{c}-1.08^{* *} \\
(0.54)\end{array}$ & $\begin{array}{l}-1.23 \\
(2.31)\end{array}$ & $\begin{array}{c}1.09^{* * *} \\
(0.32)\end{array}$ \\
\hline Polls RRP & $\begin{array}{l}-0.04 \\
(0.19)\end{array}$ & $\begin{array}{c}0.23 \\
(0.15)\end{array}$ & $\begin{array}{c}-0.28^{* * *} \\
(0.10)\end{array}$ & $\begin{array}{c}1.37^{* * *} \\
(0.38)\end{array}$ & $\begin{array}{l}-0.50 \\
(0.45)\end{array}$ & $\begin{array}{l}-0.20 \\
(0.31)\end{array}$ & $\begin{array}{c}0.18 \\
(0.33)\end{array}$ & $\begin{array}{c}0.06 \\
(0.19)\end{array}$ \\
\hline Public salience & $\begin{array}{c}3.04^{* * *} \\
(0.58)\end{array}$ & $\begin{array}{c}3.41^{* * *} \\
(0.66)\end{array}$ & $\begin{array}{c}4.08^{* * *} \\
(0.83)\end{array}$ & $\begin{array}{c}0.64 \\
(0.62)\end{array}$ & $\begin{array}{c}7.13 \\
(8.74)\end{array}$ & $\begin{array}{c}3.31^{* * *} \\
(0.66)\end{array}$ & $\begin{array}{c}20.60^{* * *} \\
(6.59)\end{array}$ & $\begin{array}{c}3.16^{* * *} \\
(0.58)\end{array}$ \\
\hline Constant & $\begin{array}{c}9.44^{* * *} \\
(2.99)\end{array}$ & $\begin{array}{c}0.00 \\
(3.85)\end{array}$ & $\begin{array}{c}12.62^{* * *} \\
(1.03)\end{array}$ & $\begin{array}{l}-8.53 \\
(6.91)\end{array}$ & $\begin{array}{c}19.25^{* *} \\
(8.15)\end{array}$ & $\begin{array}{c}17.19 * * * \\
(5.96)\end{array}$ & $\begin{array}{c}6.06 \\
(7.85)\end{array}$ & $\begin{array}{l}8.08^{* *} \\
(3.14)\end{array}$ \\
\hline Salience of immigration (lag 1) & $\checkmark$ & $\checkmark$ & $\checkmark$ & $\checkmark$ & $\checkmark$ & $\checkmark$ & $\checkmark$ & $\checkmark$ \\
\hline Salience of immigration (lag 2) & $\checkmark$ & $\checkmark$ & $\checkmark$ & $\checkmark$ & $\checkmark$ & $\checkmark$ & $\checkmark$ & $\checkmark$ \\
\hline Observations & 646 & 209 & 299 & 138 & 286 & 188 & 172 & 646 \\
\hline Number of parties & 14 & 4 & 6 & 4 & 13 & 14 & 13 & 14 \\
\hline
\end{tabular}

Robust standard errors in parentheses.

${ }^{* * *} p<0.01,{ }^{* *} p<0.05,{ }^{*} p<0.1$ 
parties' positions are rather stable. Notably, we see a small shift in the positions of ÖVP and the Greens during the refugee crisis. SPÖ's and FPÖ's positions are rather stable, while our estimates for NEOS during 2017 are inconsistent. Overall, we do not see similar changes as observable for salience.

The second set of plots in Figure 5 depicts the position estimates for Germany. Compared to Austria, shifts are more pronounced. Most notably, AfD increasingly radicalizes its antiimmigration stance. This finding is in line with previous research on the party (Arzheimer and Berning, 2019). Additionally, CSU progressively takes an anti-immigration position, more and more diverging from its sister-party CDU. This mirrors a growing and heated conflict during the refugee crisis: Horst Seehofer, the by-then CSU party leader, and his sharp criticism of Chancellor Merkel filled the headlines for weeks. The Greens' pro-immigration stance only shows small changes that do not seem to be systematically related to the refugee crisis. The positions of CDU, SPD, and the Left are very stable throughout the whole period, although individual estimates for SPD deviate considerably.

Our results for Switzerland in the third set of plots in Figure 5 show the clearest position shifts of mainstream parties. While CVP and FDP remain stable, the Greens and the Social democrats alter their position notably to a more positive stance for a prolonged period. This development begins in early 2014 and might hence be related to the popular votes on immigration taking place in February and November 2014. Interestingly, this trend continues until fall 2015, the beginning of the refugee crisis. Since then, the Greens and the Social democrats again turned more negative regarding immigration. Unsurprisingly, SVP holds the most anti-immigration stance. While the smoothed line is relatively stable until early 2016, more extreme monthly scores are present throughout the period. From mid-2016 onward, SVP moderates its position, moving toward the other parties' position. This temporally coincides with a decline of SVP's emphasis on immigration as shown in Figure 4 and may show a re-orientation of the party: After a long period of mobilization against immigration using popular votes, the defeat of its "Durchsetzungsinitiative" marked a turning point for SVP.

Overall, radical right parties exhibit by far the most critical stances on immigration. While some mainstream parties like CSU adjust their position, most do not. Moreover, some parties like ÖVP take more positive stances on immigration during the refugee crisis. In the following section, we shed light on the factors that drive mainstream parties' positions on immigration using regression analyses.

\subsection{Dynamics of positional change}

Following the same research design as for salience, we carry out regression analyses for party positions using Arellano-Bond estimators. We again present models with split-samples and use the same control variables. Considering the three different options for mainstream parties presented in our theoretical model, i.e. sticking to positions, being adversarial, or accommodating the radical right, we find mostly null results in line with our expectations in Hypothesis $2 \mathrm{~b}$. The only exceptions are German parties which take more positive positions when radical right parties become more critical, as the negative and significant coefficient in model 3 suggests. Additionally, we find a positive association of radical right parties' concurrent position with mainstream parties' immigration stances during the crisis. This differs from our expectation set out in Hypothesis $2 \mathrm{~b}$, although the negative (but not significant) lagged effect suggests such shifts may not be permanent.

Concerning center-right parties, we cannot confirm our hypothesis that these parties will adjust their positions following radical right parties (Hypothesis $3 \mathrm{~b}$ ). The coefficient of the interaction term in model 8 presents a null finding of no such effect. Note, however, that this differs by country (see Table 3): we can confirm the expectation of a (statistically significant) effect for Switzerland both regarding the concurrent and the lagged effect. In contrast, the concurrent effect 
A Positions on immigration in Austria

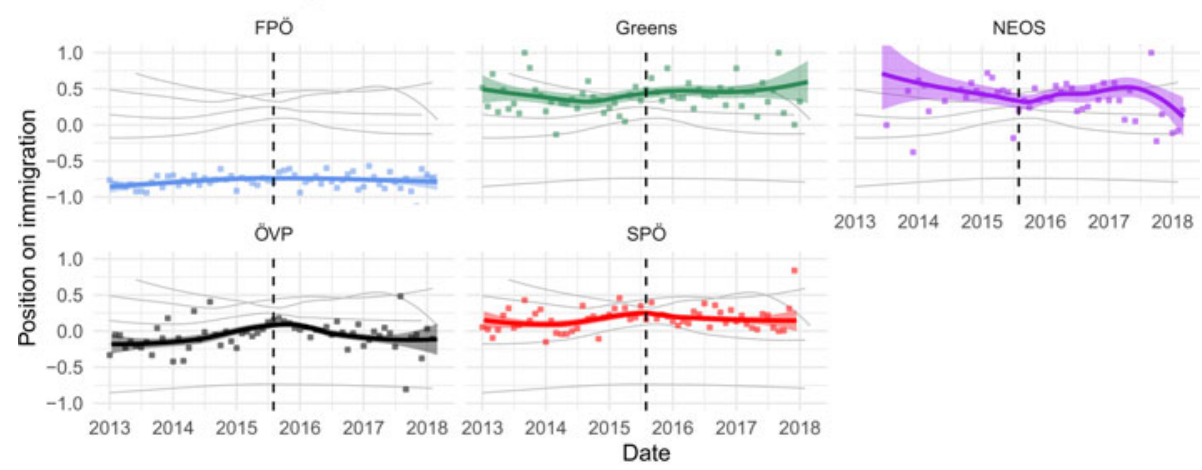

B Positions on immigration in Germany
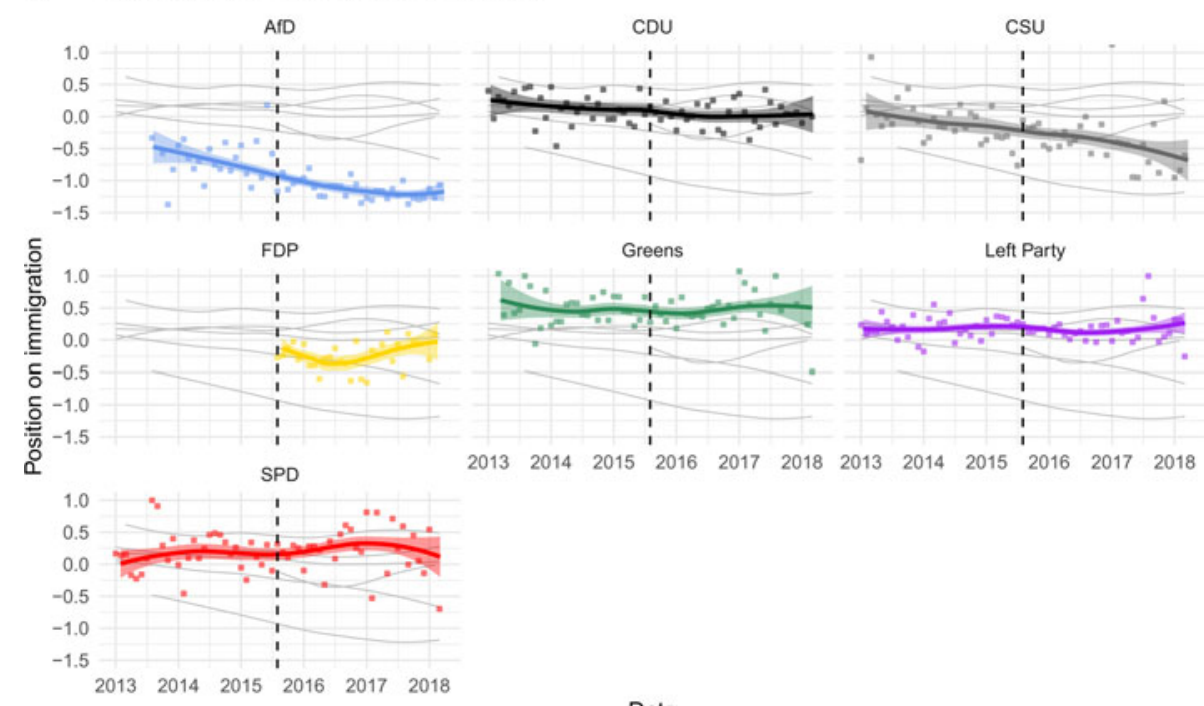

$\begin{array}{llllllllllll}2013 & 2014 & 2015 & 2016 & 2017 & 2018 & 2013 & 2014 & 2015 & 2016 & 2017 & 2018\end{array}$

\section{Positions on immigration in Switzerland}

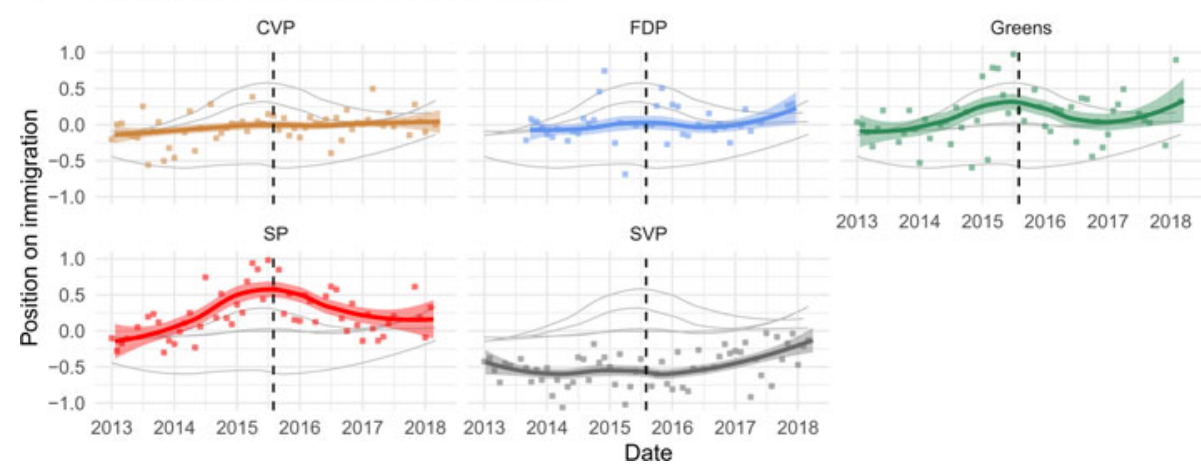

Figure 5. Estimated party positions on immigration in 3 countries.

is negative for Austria and Germany but positive for the lagged effect. For Austria, this finding is statistically significant. Overall, these findings for center-right parties indicate slower responses in terms of positions, which cannot be adjusted as easily as salience and are more dependent on party-internal consultations. 
Table 3. Regression results for mainstream parties' positions on immigration

\begin{tabular}{|c|c|c|c|c|c|c|c|c|}
\hline & $\begin{array}{l}(1) \\
\text { All }\end{array}$ & $\begin{array}{l}(2) \\
\text { AT }\end{array}$ & $\begin{array}{l}\text { (3) } \\
\mathrm{DE}\end{array}$ & $\begin{array}{l}(4) \\
\mathrm{CH}\end{array}$ & $\begin{array}{l}\text { (5) } \\
\text { Before }\end{array}$ & $\begin{array}{l}\text { (6) } \\
\text { During }\end{array}$ & $\begin{array}{l}\text { (7) } \\
\text { After }\end{array}$ & $\begin{array}{l}\text { (8) } \\
\text { Center-right }\end{array}$ \\
\hline RRP's position on immigration & $\begin{array}{l}0.00 \\
(0.03)\end{array}$ & $\begin{array}{l}0.14 \\
(0.13)\end{array}$ & $\begin{array}{l}-0.08^{* * *} \\
(0.03)\end{array}$ & $\begin{array}{l}0.04 \\
(0.09)\end{array}$ & $\begin{array}{l}-0.06 \\
(0.05)\end{array}$ & $\begin{array}{l}0.16^{* *} \\
(0.07)\end{array}$ & $\begin{array}{l}0.03 \\
(0.10)\end{array}$ & $\begin{array}{l}0.02 \\
(0.04)\end{array}$ \\
\hline RRP's position on immigration (lag 1 ) & $\begin{array}{l}-0.02 \\
(0.04)\end{array}$ & $\begin{array}{l}-0.12 \\
(0.21)\end{array}$ & $\begin{array}{l}-0.03 \\
(0.07)\end{array}$ & $\begin{array}{l}-0.12 \\
(0.08)\end{array}$ & $\begin{array}{l}-0.04 \\
(0.05)\end{array}$ & $\begin{array}{l}-0.12 \\
(0.07)\end{array}$ & $\begin{array}{l}0.03 \\
(0.09)\end{array}$ & $\begin{array}{l}-0.06 \\
(0.07)\end{array}$ \\
\hline $\mathrm{CR}$ & & & & & & & & $\begin{array}{l}0.00 \\
(0.00)\end{array}$ \\
\hline Center-right * RRP's position on imm. & & & & & & & & $\begin{array}{l}-0.04 \\
(0.06)\end{array}$ \\
\hline Center-right * RRP's position on imm. (lag 1$)$ & & & & & & & & $\begin{array}{l}0.11 \\
(0.07)\end{array}$ \\
\hline Asylum applications (N) & $\begin{array}{l}0.00 \\
(0.01)\end{array}$ & $\begin{array}{l}0.02^{* *} \\
(0.01)\end{array}$ & $\begin{array}{l}-0.01 \\
(0.02)\end{array}$ & $\begin{array}{l}-0.01 \\
(0.01)\end{array}$ & $\begin{array}{l}0.01 \\
(0.04)\end{array}$ & $\begin{array}{l}0.04^{* * *} \\
(0.01)\end{array}$ & $\begin{array}{l}-0.20 \\
(0.17)\end{array}$ & $\begin{array}{l}0.00 \\
(0.01)\end{array}$ \\
\hline Polls RRP & $\begin{array}{l}0.00 \\
(0.00)\end{array}$ & $\begin{array}{l}0.00 \\
(0.00)\end{array}$ & $\begin{array}{l}-0.01 \\
(0.01)\end{array}$ & $\begin{array}{l}0.03 \\
(0.03)\end{array}$ & $\begin{array}{l}-0.01 \\
(0.01)\end{array}$ & $\begin{array}{l}-0.01 \\
(0.01)\end{array}$ & $\begin{array}{l}-0.01 \\
(0.01)\end{array}$ & $\begin{array}{l}0.00 \\
(0.00)\end{array}$ \\
\hline Public salience & $\begin{array}{l}0.00 \\
(0.01)\end{array}$ & $\begin{array}{l}0.00 \\
(0.02)\end{array}$ & $\begin{array}{l}-0.01 \\
(0.01)\end{array}$ & $\begin{array}{l}0.01 \\
(0.02)\end{array}$ & $\begin{array}{l}0.13 \\
(0.28)\end{array}$ & $\begin{array}{l}-0.00 \\
(0.01)\end{array}$ & $\begin{array}{l}0.45 \\
(0.31)\end{array}$ & $\begin{array}{l}0.00 \\
(0.01)\end{array}$ \\
\hline Position on immigration (lag 1 ) & $\checkmark$ & $\checkmark$ & $\checkmark$ & $\checkmark$ & $\checkmark$ & $\checkmark$ & $\checkmark$ & $\checkmark$ \\
\hline Position on immigration (lag 2) & $\checkmark$ & $\checkmark$ & $\checkmark$ & $\checkmark$ & $\checkmark$ & $\checkmark$ & $\checkmark$ & $\checkmark$ \\
\hline Constant & $\begin{array}{l}0.12 \\
(0.08)\end{array}$ & $\begin{array}{l}0.21 \\
(0.29)\end{array}$ & $\begin{array}{l}0.10 \\
(0.11)\end{array}$ & $\begin{array}{l}-0.43 \\
(0.43)\end{array}$ & $\begin{array}{l}0.23 \\
(0.23)\end{array}$ & $\begin{array}{l}0.31^{* * *} \\
(0.10)\end{array}$ & $\begin{array}{l}0.36 \\
(0.33)\end{array}$ & $\begin{array}{l}0.13 \\
(0.08)\end{array}$ \\
\hline Observations & 646 & 209 & 299 & 138 & 286 & 188 & 172 & 646 \\
\hline Number of parties & 14 & 4 & 6 & 4 & 13 & 14 & 13 & 14 \\
\hline
\end{tabular}

Robust standard errors in parentheses.

**** $p<0.01, * * p<0.05,{ }^{*} p<0.1$.

Beyond the lack of a significant effect in almost all models, we want to highlight the small effect sizes in most specifications, as party positions are overall rather stable. Additionally, all control variables have no effect. Only the monthly asylum applications show a small positive effect on mainstream parties' positions for the crisis-period in models 2 and 6 .

\section{Conclusion}

In this paper, we studied how crises shape party competition, specifically short-term responsiveness to challengers. We did so based on the impact of radical right parties on mainstream parties' emphasis and positions on immigration in the context of the refugee crisis in Austria, Germany, and Switzerland. We proposed that-next to the direct effect of the crisis-mainstream parties' reactions are based on a two-step decision model that we derived from Meguid's seminal framework for mainstream party strategies. Our results show that parties were forced to increase their immigration emphasis but mostly maintained their previous positions. That is, mainstream parties' attention to immigration was not only affected by the crisis itself but also driven by radical right parties' emphasis on the topic.

By drawing attention to short-term dynamics, our approach departs from much of the existing research. We believe these dynamics are complementary to the long-term changes which have been the primary focus of existing scholarship. Our findings suggest that a high-paced short-term contagion for salience exists and primarily occurs within the same month. This implies that beyond the long-term strategies outlined in party manifestos, parties also react to their competitors within days or weeks in their press releases. This supports similar research on short-term agenda setting on social media (Gilardi et al., 2021). Notably, our results hold for all three 
time periods, i.e. also before and after the crisis when we can assume that there are fewer migration-related events that might confound our analyses. ${ }^{8}$

In contrast, with regard to positions, our findings point to a diminished responsiveness toward the radical right. Namely, most parties' positions on immigration are rather stable and we find little evidence that parties took more negative stances during the refugee crisis (with the important exceptions of FDP and CSU). In a regression framework, the radical right's impact on parties is rather limited and we only find evidence for such an effect during the immediate crisis period and in Germany-where most parties have seemingly taken a more adversarial stance toward the radical right. A key reason for this limited reaction may be that positional change occurs at a slower pace which we miss with our model specification. As our study constitutes the first empirical analysis of these immediate dynamics for positions, it complements previous research that mostly studied contagion from one election to the next but cannot provide definite answers. This holds especially as our results depend on the cases we study. We suspect the adversarial reaction in Germany may be due to the specifics of the case: Unlike the well-established radical right parties in Austria and Switzerland, the AfD constituted a new challenger and hence sparked a different reaction. This may be a result of coalition considerations. As the AfD was considered a pariah party, none of its competitors considered the option of a coalition in the near future (Bräuninger et al., 2019). This allowed parties to be less responsive both in terms of salience, where contagion effects are not significant for Germany, and in terms of positions, where parties may have found it easier to confront the AfD. ${ }^{9}$

While we do find short-term contagion in terms of salience, our findings also speak to limitations regarding the broader effect of crises: After a short period, most parties' attention to immigration peters out, despite the leap in salience at the beginning of the crisis. This decline provides important context for the interpretation of any changes found in research focused on changes from one election to the next. Moreover, we find that the crisis affects the level of attention to immigration but does not alter the logic of party competition: Salience contagion is already in place before the refugee crisis and continues to exist in the post-crisis period. Nevertheless, the higher baseline salience of immigration during the crisis makes this contagion all the more powerful in terms of its substantive effect.

Regardless of the time interval researchers choose to analyze, an important take-away from our findings is the importance of expanding Meguid's model by assessing changes in salience and positions separately. It seems that both the presence and pace of mainstream parties' responses may be different for salience and positions. This might be explained by a higher degree of flexibility in terms of salience, compared to positions. Empirically, our research suggests that the refugee crisis provided momentum for radical right parties, as they consistently managed to exert pressure on other parties, even in a situation of high immigration salience. However, this did not apply to positions to the same extent. As the effect for salience plays out quite similarly in all three countries, we conclude that-despite the differences between our cases-radical right parties (and potentially challengers more broadly) play a functionally equivalent role during crises in different contexts. When they are provided with a favorable political opportunity structure, they will increase attention to their agenda and seem to move their competitors to do so, too.

Supplementary material. The supplementary material for this article can be found at https://doi.org/10.1017/psrm.2021.64.

Acknowledgements. The authors wish to thank Anja Neundorf and the anonymous reviewers for their comments and guidance. We are greatful to Tarik Abou-Chadi, Raffaele Grotti, Elisabeth Ivarsflaten, Heike Klüver, Hanspeter Kriesi, Giorgio Malet, Stefan Müller and Gijs Schumacher for their help and feedback on previous versions of this paper.

\footnotetext{
${ }^{8}$ As discussed in the paper, in order to rule out event-specific confounders, we have controlled for the public salience of immigration and the number of asylum applications.

${ }^{9} \mathrm{An}$ important caveat is that we cannot address to which extent parties really took a more positive stance or merely adopted pragmatic politics and used humanitarian frames given the context of crisis. Hence, looking into the changing framing of the immigration issue in Germany may be an important avenue for further research.
} 
Additionally, our paper was greatly improved by feedback from participants and discussants at ECPR, EPSA, MPSA and SISP as well as a workshop on parties in the electoral cycle organized by Alexandra Feddersen and Thomas Meyer and a seminar at the University of Zurich.

\section{References}

Abou-Chadi T (2016) Niche party success and mainstream party policy shifts-how green and radical right parties differ in their impact. British Journal of Political Science 46, 417-436.

Abou-Chadi T, Green-Pedersen C and Mortensen PB (2020) Parties' policy adjustments in response to changes in issue saliency. West European Politics 43, 749-771.

Alonso S and da Fonseca SC (2012) Immigration, left and right. Party Politics 18, 865-884.

Ansolabehere S and Iyengar S (1994) Riding the wave and claiming ownership over issues: the joint effects of advertising and news coverage in campaigns. Public Opinion Quarterly 58, 335-357.

Arellano M and Bond S (1991) Some tests of specification for panel data: Monte Carlo evidence and an application to employment equations. The Review of Economic Studies 58, 277-297.

Arzheimer K and Berning CC (2019) How the Alternative for Germany (AfD) and their voters veered to the radical right, 2013-2017. Electoral Studies 60, 1-10.

Bale T (2003) Cinderella and her ugly sisters: the mainstream and extreme right in Europe's bipolarising party systems. West European Politics 26, 67-90.

Bale T, Green-Pedersen C, Krouwel A, Luther KR and Sitter N (2010) If you can't beat them, join them? Explaining social democratic responses to the challenge from the populist radical right in Western Europe. Political Studies 58, 410-426.

Benoit K, Watanabe K, Wang H, Nulty P, Obeng A, Müller S and Matsuo A (2018) Quanteda: an R package for the quantitative analysis of textual data. Journal of Open Source Software 3, 774.

Betz H-G (2002) Conditions favouring the success and failure of radical right-wing populist parties in contemporary democracies. In Yves M and Surel Y (eds.), Democracies and the Populist Challenge. Basingstoke: Palgrave, pp. 197-213.

Bräuninger T, Debus M, Müller J and Stecker C (2019) Party competition and government formation in Germany: business as usual or new patterns?. German Politics 28, 80-100.

Bremer B and Schulte-Cloos J (2019) Restructuring British and German party politics in times of crises. In Swen H and Kriesi H. Restructuring European Party Politics in Times of Crises. Cambridge: Cambridge University Press.

Chykina V and Crabtree C (2018) Using Google trends to measure issue salience for hard-to-survey populations. Socius 4.

Dalton RJ and McAllister I (2015) Random walk or planned excursion? Continuity and change in the left-right positions of political parties. Comparative Political Studies 48, 759-787.

Dancygier R and Margalit Y (2019) The evolution of the immigration debate: evidence from a new dataset of party positions over the last half-century. Comparative Political Studies 53, 734-774.

Dolezal M, Ennser-Jedenastik L, Müller WC and Winkler AK (2012) The life cycle of party manifestos: the Austrian case. West European Politics 35, 869-895.

European Commission (2018) Eurobarometer. Public Opinion in the European Union Report. Cologne: GESIS Data Archive.

Fennema M and Van Der Brug W (2003) Protest or mainstream? How the European anti-immigrant parties developed into two separate groups by 1999. European Journal of Political Research 42, 55-76.

FORS, ZDA (2018) VOTO-Surveys on the Swiss Popular Votes, 2016-2018. FORS-Centre of expertise in the social sciences, Centre for Democracy Studies Aarau (ZDA), University of Zurich. Distributed by FORS, Lausanne.

Geers S and Bos L (2017) Priming issues, party visibility, and party evaluations: the impact on vote switching. Political Communication 34, 344-366.

Gilardi F, Gessler T, Kubli M and Müller S (2021) Social media and political agenda setting. Political Communication, 1-22. http://dx.doi.org/10.1080/10584609.2021.1910390.

Grande E, Schwarzbözl T and Fatke M (2019) Politicizing immigration in Western Europe. Journal of European Public Policy 26, 1444-1463.

Granka L (2013) Using online search traffic to predict us presidential elections. PS: Political Science \& Politics 46, 271-279.

Green-Pedersen C (2007) The growing importance of issue competition: the changing nature of party competition in Western Europe. Political Studies 55, 607-628.

Green-Pedersen C (2019) The Reshaping of West European Party Politics: Agenda-Setting and Party Competition in Comparative Perspective, 1st Edn. Comparative Politics. Oxford: Oxford University Press.

Green-Pedersen C and Otjes S (2017) A hot topic? Immigration on the agenda in Western Europe. Party Politics 25, 424-434.

Greussing E and Boomgaarden HG (2017) Shifting the refugee narrative? An automated frame analysis of Europe's 2015 refugee crisis. Journal of Ethnic and Migration Studies 43, 1749-1774.

Grimmer J (2013) Appropriators not position takers: the distorting effects of electoral incentives on congressional representation. American Journal of Political Science 57, 624-642.

Harteveld E, Schaper J, De Lange SL and Van Der Brug W (2018) Blaming Brussels? The impact of (news about) the refugee crisis on attitudes towards the Eu and national politics. JCMS: Journal of Common Market Studies 56, 157-177. 
Hooghe L and Marks G (2017) Cleavage theory meets Europe's crises: Lipset, Rokkan, and the transnational cleavage. Journal of European Public Policy 25, 109-135.

Hopmann DN, Vliegenthart R, De Vreese C and Albæk E (2010) Effects of election news coverage: how visibility and tone influence party choice. Political Communication 27, 389-405.

Hopmann DN, Elmelund-Præstekær C, Albæk E, Vliegenthart R and de Vreese CH (2012) Party media agenda-setting: how parties influence election news coverage. Party Politics 18, 173-191.

Hutter S and Gessler T (2019) The media content analysis and cross-validation. In Swen H and Hanspeter K (eds), Restructuring European Party Politics in Times of Crises. Cambridge: Cambridge University Press, pp. 53-72.

Hutter S and Kriesi H (2018) Restructuring the party systems in North-Western Europe. Six countries compared. Conference: 2017: Europe's Bumper Year of Elections, Proceedings. Florence: European University Institute.

Hutter S and Kriesi H (eds) (2019) European Party Politics in Times of Crises. Cambridge: Cambridge University Press.

Hutter S, Kriesi H and Vidal G (2018) Old versus new politics: the political spaces in Southern Europe in times of crises. Party Politics 24, 10-22.

Ivarsflaten E (2008) What unites right-wing populists in Western Europe?: re-examining grievance mobilization models in seven successful cases. Comparative Political Studies 41, 3-23.

Iyengar S and Kinder D (1987) News That Matters. Chicago: University of Chicago Press.

Klüver H and Sagarzazu I (2016) Setting the agenda or responding to voters? Political parties, voters and issue attention. West European Politics 39, 380-398.

Kriesi H, Grande E, Lachat R, Dolezal M, Bornschier S and Frey T (eds) (2008) West European Politics in the Age of Globalization. Cambridge: Cambridge University Press.

Kriesi H, Grande E, Dolezal M, Helbling M, Hoeglinger D, Hutter S and Wueest B (2012) Political Conflict in Western Europe. Cambridge: Cambridge University Press.

Kriesi H, Brunner M and Lorétan F (2016) Standardisierte Umfragen VoxIt 1981-2016. FORS, Lausanne: Université de Genève, Universität Zürich.

Kriesi H, Grande E, Hutter S, Altiparmakis A, Borbáth E, Bornschier S, Bremer B, Dolezal M, Frey T, Gessler T, Helbling M, Höglinger M, Lachat R, Lorenzini J, Malet G, Vidal G and Wüest B (2020) PolDem-national election campaign dataset.

Laver M, Benoit K and Garry J (2003) Extracting policy positions from political texts using words as data. American Political Science Review 97, 311-331.

Lefkofridi Z, Wagner M and Willmann JE (2014) Left-authoritarians and policy representation in Western Europe: electoral choice across ideological dimensions. West European Politics 37, 65-90.

Lowe W (2008) Understanding wordscores. Political Analysis 16, 356-371.

Mader M and Schoen H (2018) The European refugee crisis, party competition, and voters' responses in Germany. West European Politics 42, 67-90.

McGann AJ and Kitschelt H (2005) The radical right in the Alps: evolution of support for the Swiss SVP and Austrian FPÖ. Party Politics 11, 147-171.

Meguid B (2005) Competition between unequals: rhe role of mainstream party strategy in Niche party success. American Political Science Review 99, 347-359.

Meguid B (2008) Party Competition Between Unequals. Strategies and Electoral Fortunes in Western Europe. Cambridge: Cambridge University Press.

Mellon J (2013) Where and when can we use Google trends to measure issue salience?. PS: Political Science \& Politics 46, 280-290.

Meyer S and Rosenberger S (2015) Just a shadow? The role of radical right parties in the politicization of immigration, 19952009. Politics and Governance 3, 1-17.

Meyer TM and Wagner M (2021) Issue engagement across members of parliament: the role of issue specialization and party leadership. Legislative Studies Quarterly 46(3), 653-678.

Mudde C (2010) The populist radical right: a pathological normalcy. West European Politics 33, 1167-1186.

Muddiman A, McGregor SC and Stroud NJ (2018) (Re)claiming our expertise: parsing large text corpora with manually validated and organic dictionaries. Political Communication 36, 214-226.

Pauwels T (2011) Measuring populism: a quantitative text Analysis of party literature in Belgium. Journal of Elections, Public Opinion and Parties 21, 97-119.

Rooduijn M and Pauwels T (2011) Measuring oopulism: comparing two methods of content analysis. West European Politics 34, 1272-1283.

Ruedin D (2013) Obtaining party positions on immigration in Switzerland: comparing different methods. Swiss Political Science Review 19, 84-105.

Ruedin D and Morales L (2017) Estimating party positions on immigration: assessing the reliability and validity of different methods. Party Politics 25, 303-314.

Schumacher G and van Kersbergen K (2016) Do mainstream parties adapt to the welfare Chauvinism of populist parties?. Party Politics 22, 300-312. 
Seeberg HB (2017) How stable is political parties' issue ownership? A cross-time, cross-national analysis. Political Studies 65 , 475-492.

Sides J (2006) The origins of campaign agendas. British Journal of Political Science 36, 407-436.

Siliverstovs B and Wochner DS (2018) Google trends and reality: do the proportions match?: appraising the informational value of online search behavior. Journal of Economic Behavior \& Organization 145, 1-23.

Thesen G, Green-Pedersen C and Mortensen PB (2017) Priming, issue ownership, and party support: the electoral gains of an issue-friendly media agenda. Political Communication 34, 282-301.

Udris L (2012) Is the populist radical tight (still) shaping the news? Media attention, issue ownership and party strategies in Switzerland. Challenges to Democracy in the 21st Century. NCCR Working Paper 53.

Van Der Brug W and van Spanje J (2009) Immigration, Europe and the "new" cultural dimension. European Journal of Political Research 48, 309-334.

Van Spanje J (2010) Contagious parties: anti-immigration Parties and their impact on other parties' immigration stances in contemporary Western Europe. Party Politics 16, 563-586.

Volkens A, Lehmann P, Matthieß T, Merz N and Regel S (2016) The Manifesto data collection. Manifesto Project. Version 2016b.

Walgrave S, Lefevere J and Nuytemans M (2009) Issue ownership stability and change: how political parties claim and maintain issues through media appearances. Political Communication 26, 153-172.

Walgrave S, Lefevere J and Tresch A (2012) The associative dimension of issue ownership. Public Opinion Quarterly 76, 771-782.

Walgrave S, Tresch A and Lefevere J (2015) The conceptualisation and measurement of issue ownership. West European Politics 38, 778-796.

Cite this article: Gessler T, Hunger S (2022). How the refugee crisis and radical right parties shape party competition on immigration. Political Science Research and Methods 10, 524-544. https://doi.org/10.1017/psrm.2021.64 